YEARBOOK

of ANTITRUST

and REGULATORY

STUDIES

www.yars.wz.uw.edu.pl
Peer-reviewed scientific periodical, focusing on legal and economic issues of antitrust and regulation. Creative Commons Attribution-No Derivative Works 3.0 Poland License.

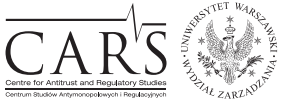

Centre for Antitrust and Regulatory Studies, University of Warsaw, Faculty of Management www.cars.wZ.uw.edu.pl

\title{
Collective Proceedings for Damages in UK Competition Law Case Comment to the Judgment Merricks $v$ Mastercard [2019] EWCA Civ 674
}

\author{
by
}

Kathryn McMahon*

\section{CONTENTS}

I. Introduction

II. The UK legislative regime for collective proceedings

III. The private right to damages for breach of competition law

IV. The facts in issue in Merricks $v$ Mastercard

V. The requirements for certification of a Collective Proceedings Order (CPO)

VI. The methodology for calculation of the 'Pass-on'

VII. The common issues of fact or law

VIII. The sufficiency of data for the grant of the CPO

IX. The method of distribution of the aggregate award

$\mathrm{X}$. Conclusion

\section{Abstract}

Merricks v Mastercard [2019] is the first action under the newly developed 'opt-out' collective proceedings regime for aggregate damages under UK competition law to be considered by the UK Court of Appeal. It is significant for both the level of damages ( $£ 14$ billion ( $€ 16$ billion)) and the clarification of the legal test at the certification stage for the suitability for an aggregate award: the method for calculation of the aggregate damages and the sufficiency of evidence. The Court's lowering of these thresholds importantly opens the door to future class actions and reasserts the importance of collective proceedings as a valuable means of redress for competition law infringements. The decision has now been

* Associate Professor, School of Law, University of Warwick, UK. Article received: 9 June 2019; accepted: 1 July 2019. 
appealed to the UK Supreme Court where these issues may be further clarified and resolved.

\section{Résumé}

Merricks v Mastercard [2019] est la première action examinée par la Cour d'appel du Royaume-Uni, dans le cadre du nouveau régime de procédure collective «opt-out» récemment mis au point en vertu du droit britannique de la concurrence. Cette action est importante tant pour le niveau des dommages (14 milliards de $£ ; 16$ milliards de $€)$ que pour la clarification du test juridique au stade de la certification de l'aptitude à une indemnisation globale: la méthode de calcul du dommage et le caractère suffisant des preuves. Labaissement de ces seuils par la Cour ouvre la voie à de futurs recours collectifs et réaffirme l'importance des procédures collectives en tant que moyen utile de réparation pour les infractions au droit de la concurrence. La décision a maintenant fait l'objet d'un appel devant la Cour suprême du Royaume-Uni, où ces questions peuvent être clarifiées et résolues.

Key words: UK Competition Law, EU Competition Law, class actions, collective proceedings, certification stage, damages.

JEL: K2, K3, L4, M2

\section{Introduction}

On the 16 April 2019, the UK Court of Appeal (Patten, Hamblen and Coulson LJJ) allowed an appeal by representative Walter Merricks against a judgment of the UK Competition Appeal Tribunal (hereinafter: CAT) refusing to grant a Collective Proceedings Order (hereinafter: CPO) against three companies in the Mastercard group. ${ }^{1}$ Merricks' action seeks to represent an estimated class of 46.2 million people, in an aggregate award of damages worth $£ 14.098$ billion ( $€ 15.7$ billion). Leave has been granted for an appeal of the decision to the UK Supreme Court.

This was the first action under the newly developed 'opt-out' collective proceedings regime for aggregate damages under UK competition law to be considered by the Court of Appeal. The judgment provides an important interpretation of the new legislative regime, in particular the standard of evidence required for a $\mathrm{CPO}$ application. ${ }^{2}$

\footnotetext{
${ }^{1}$ Merricks v Mastercard [2019] EWCA Civ 674 (UK Court of Appeal).

2 In Gibson v Pride Mobility Products (2017) CAT 9, the CAT had certified a CPO in a collective action for damages for losses by consumers who bought a scooter from one of
} 


\section{The UK legislative regime for collective proceedings}

The UK regime for damages permits 'stand-alone' (where the applicant bears the burden of proof for the infringement) or 'follow-on' (the applicant can rely on a previous public or private decision and is relieved of proof of liability) ${ }^{3}$ actions to be brought before the CAT or High Court for damages arising under the Competition Act 1998 (CA) (UK) (s47A) and Articles 101 and 102 of the Treaty on the Functioning of the European Union (TFEU).

The Consumer Rights Act 2015 (UK) introduced amendments (ss 47B and 47C CA) to allow the bringing of collective proceedings for these damages in the CAT. Section 47B requires that collective proceedings must be commenced by a person who proposes to be the representative ( $\mathrm{s} 47 \mathrm{~B}(2))$ and may only continue if the Tribunal makes a collective proceedings order (CPO) $(\mathrm{s} 47 \mathrm{~B}(4))$.

The Tribunal may make a CPO only if:

S47B (5)(a) ...the person who brought the proceedings is a person who, if the order were made, the Tribunal could authorise to act as the representative in those proceedings; and

(5) (b) in respect of claims which are eligible for inclusion in collective proceedings.

(6) Claims are eligible for inclusion in collective proceedings only if the Tribunal considers that they raise the same, similar or related issues of fact or law...

(7) A collective proceedings order must include the following matters-

(a) authorisation of the person who brought the proceedings to act as the representative in those proceedings,

(b) description of a class of persons whose claims are eligible for inclusion in the proceedings.

The eligibility rules for a $\mathrm{CPO}$ under s.47B(6) are further incorporated into Rule 77(1)(b) (Competition Appeal Tribunal Rules 2015 (2015 No. 1648) made under s 15 of the Enterprise Act 2002 ('the Rules')) which directs eligibility to be determined in accordance with Rule 79 .

Rule 79(1) states:

(1) The Tribunal may certify claims as eligible for inclusion in collective proceedings where, having regard to all the circumstances, it is satisfied by the proposed class representative that the claims sought to be included in the collective proceedings-

eight retailers found to be fixing resale prices in breach of the Competition Act 1998 (UK). The case was ultimately withdrawn however due to an error in the economic expert calculation of damages arising from the 'follow-on' action.

3 The decision is binding proof that the behavior took place and was illegal: Regulation 1/2003, Article 16; Competition Act 1998 (UK), s58A. 
(a) are brought on behalf of an identifiable class of persons;

(b) raise common issues; and

(c) are suitable to be brought in collective proceedings. ${ }^{4}$

\section{The private right to damages for breach of competition law}

EU competition law places importance on the establishment of private rights to damages for loss caused by a breach of competition law. ${ }^{5}$ The UK collective damages provisions were introduced to facilitate these actions. These collective proceedings may be brought on an opt-out or opt-in basis. Prior to reform there was no UK direct equivalent of the US 'opt-out' model of class action for competition claims in which one or more parties can bring an action on behalf of a large class matching a particular description which includes absent or unidentified parties, except for those who have expressly chosen not to participate (for a discussion of the purposes and background to the reforms: see: Mulheron and Edlin, 2018, p. 224-227).

${ }^{4}$ Rule 79 (2) In determining whether the claims are suitable to be brought in collective proceedings for the purposes of paragraph (1)(c), the Tribunal shall take into account all matters it thinks fit, including-

(a) whether collective proceedings are an appropriate means for the fair and efficient resolution of the common issues;

(b) the costs and the benefits of continuing the collective proceedings;

(c) whether any separate proceedings making claims of the same or a similar nature have already been commenced by members of the class;

(d) the size and the nature of the class;

(e) whether it is possible to determine in respect of any person whether that person is or is not a member of the class;

(f) whether the claims are suitable for an aggregate award of damages; and

(g) the availability of alternative dispute resolution and any other means of resolving the dispute...

(3) In determining whether collective proceedings should be opt-in or opt-out proceedings, the Tribunal may take into account all matters it thinks fit, including the following matters additional to those set out in paragraph (2) - (a)the strength of the claims; and (b)whether it is practicable for the proceedings to be brought as opt-in collective proceedings, having regard to all the circumstances, including the estimated amount of damages that individual class members may recover.

5 Case C-453/99, Courage Ltd. v. Crehan, [2001] ECR I-6297 and Joined cases C-295/04, 297/04 and 298/04 Manfredi et al.v. Lloyd Adriatico assicurazioni Spa e Assitalia Spa, [2006] ECR I-6619; Directive 2014/104/EU of 26 November 2014 on certain rules governing actions for damages under national law for infringements of the competition law provisions of the Member States and of the European Union (EU Damages Directive). 
The calculation of damages for breach of competition law is a complex task which is based on a principle of full compensation, including actual loss, loss of profit and interest. ${ }^{6}$ Compensation means placing the injured party in the position it would have been in had there been no infringement (which requires consideration of the counterfactual). The calculation requires the estimation of complex economic and statistical data and the use of large datasets, which are both difficult and costly to obtain and analyse. Unlike competitors who may have the incentive and resources to undertake these calculations, consumers are faced with diminished (including rules regarding the disclosure of evidence) and costly access to this asymmetric information. ${ }^{7}$

The proportionality of the costs and burdens on the injured party for the quantification of damages may be relevant to the EU principle of effectiveness. National law must provide an effective remedy which must not render excessively difficult or practically impossible the exercise of rights conferred on individuals. The EU Damages Directive (2014) states:

Member States shall ensure that neither the burden nor the standard of proof required for the quantification of harm renders the exercise of the right to damages practically impossible or excessively difficult. Member States shall ensure that the national courts are empowered, in accordance with national procedures, to estimate the amount of harm if it is established that a claimant suffered harm but it is practically impossible or excessively difficult precisely to quantify the harm suffered on the basis of the evidence available. ${ }^{8}$

The calculation of damages arising from a cartel, the subject of this infringement, includes the 'overcharge' (higher prices, loss of profits) paid by the direct purchaser of the goods or services which were the subject of the cartel and the 'volume effect' (loss of volume of sales). ${ }^{9}$ The calculation of the 'overcharge' is based on the counterfactual, an estimate of the non-infringement price compared to the actual price paid by the customer. The calculation can be made on comparator (different product or geographic) markets. ${ }^{10}$ The compensation available to the direct purchaser may be fully

6 Damages do not include overcompensation by punitive, multiple or other damages: EU Damages Directive (2014), recitals 12, 13.

7 EC, Quantifying Harm in Actions for Damages Draft Guidance Paper (June 2011); Communication from the Commission on quantifying harm in actions for damages (2013/C 167/07).

8 EU Damages Directive, Article 17.

${ }^{9}$ For a 'buyer cartel' there could also be an 'undercharge' for the supplier of the cartel.

10 European Commission, Guidelines for national courts on how to estimate the share of the overcharge which was passed on to the indirect purchaser (2019) (Draft) [5.1] http://ec.europa. eu/competition/antitrust/actionsdamages/passing_on_en.pdf. 
or partially (depending on level of competition and elasticity) passed on to customers, as indirect purchasers. ${ }^{11}$

The collective action in this infringement dealt with the amount of overcharge paid by consumers as indirect purchasers.

\section{The facts in issue in Merricks $v$ Mastercard}

The action for collective damages arose from a 'follow-on' action from a 19 December 2007 decision by the European Commission against Mastercard under Article 101 TFEU for the setting of a multilateral interchange fee (hereinafter: MIF) which resulted in higher fees being charged between acquiring banks. ${ }^{12}$

The background to the claim was set out by the CAT in its decision of 21 July 2017.

Mastercard operates what is commonly known as a four party payment card scheme... (1) a cardholder; (2) the cardholder's bank (known as the "Issuing Bank"); (3) a merchant; and (4) the merchant's bank (known as the "Acquiring Bank"). Issuing and Acquiring Banks ... must pay fees to Mastercard to participate in the scheme and comply with the Mastercard Scheme Rules.. The Issuing Bank transmits payment to the Acquiring Bank, less a transaction fee known as the interchange fee ("IF"). The Acquiring Bank in turn generally deducts the amount of the IF, along with a fee for its acquiring services, from the payment it makes to the merchant. The total deduction made by the Acquiring Bank from the amount paid to the merchant is called the merchant service charge ("MSC"). However, the IF accounts for the vast majority of the MSC. The Issuing Bank and the Acquiring Bank may have bilaterally agreed the level of IF that will apply to transactions between them, or in some cases they may be the same bank. But except for those situations, the level of the fee defaults to one set by Mastercard. This default fee is known as the multilateral interchange fee: the MIF... (i) where a card issued in one EEA Member State is used at a merchant based in a different EEA Member State, a cross-border MIF applies. This is the EEA MIF ... which was the subject of the EC Decision. ${ }^{13}$

The European Commission found that the setting of the EEA MIF by Mastercard constituted a decision of an association of undertakings which had the object or effect of restricting competition in breach of Article 101 TFEU.

11 EU Damages Directive, Article 12-14.

12 COMP/34.579 MasterCard (2007); European Commission, Commission prohibits MasterCard's intra-EEA Multilateral Interchange Fees, Memo IP/07/1959.

13 Merricks v Mastercard [2017] CAT 16 at [8]-[12] https://www.catribunal.org.uk/sites/ default/files/2.1266_Walter_Hugh_Judgment_CAT_16_210717.pdf. 
It was considered that the entire cost of the MIF was passed by the Acquiring Banks to merchants as part of the merchant service charge (hereinafter: MSC). Merricks sought the CAT's approval to act as class representative on behalf of all UK residents who between 1992 and 2008 purchased goods or services from businesses in the UK which accepted Mastercard. ${ }^{14}$

\section{$\mathrm{V}$. The requirements for certification of a Collective Proceedings Order (CPO)}

The CAT found Merricks was a suitable class representative but refused the CPO for two main reasons:

.... a perceived lack of data to operate the proposed methodology for determining the level of pass-on of the overcharges to consumers and the absence of any plausible means of calculating the loss of individual claimants so as to devise an appropriate method of distributing any aggregate award of damages. ${ }^{15}$

The absence of a method of distribution of the damages award was considered to not be compensatory because it would bear no relation to the actual losses sustained by any individual member of the class. ${ }^{16}$

Section 47B CA requires the CAT to determine the award of a CPO and its decision can only be challenged on judicial review 'if it could be shown that it had misapplied the relevant legal test or had made a decision on the facts before it which no reasonable tribunal, properly directed as to the law, could have reached. ${ }^{17}$

On judicial review, the Court of Appeal found that the CAT had committed an error of law in applying the wrong test on two issues.

14 Merricks [2019] EWCA Civ 674 [4]. Merrick's claim also included an additional UK MIF fee deriving from intra-UK transactions between the issuing and acquiring banks.

15 Merricks [2019] EWCA Civ 674 [29].

16 In critiquing the 'top-down' aggregate methodology the CAT claimed that the aggregate method was defective because 'if, hypothetically, a million people opted out of the proceedings, there would be no proper way of reducing the quantum of damages accordingly (and, conversely, of increasing it if a large number of people now domiciled outside the UK sought to opt in): it would simply lead to everyone in the class getting more (or less) money out of the total pot.' Merricks [2017] CAT 16 [87]. This question should arguably not be determined however at the certification stage: see Mulheron and Edlin, above n. 7, 2018, p. 240-241.

17 Merricks [2019] EWCA Civ 674 [12]. The Tribunal's decision to grant or refuse a CPO can also be appealed to the Court of Appeal: Merricks v Mastercard [2018] EWCA Civ 2527. 


\section{The methodology for calculation of the 'Pass-on'}

The first issue was the method and feasibility of calculation of the aggregate award of damages and in particular the level of MSC pass-on to consumers during the infringement period. The collective claim relied on an expert report prepared by Dr Cento Veljanovski and Mr David Dearman. The experts acknowledged that the assessment for quantifying the loss was preliminary and would require the complex analysis of further data to be disclosed by Mastercard and market studies. The experts proposed a 3-step method of calculation of the volume of all relevant UK Mastercard transactions, the extent of the overcharge in respect of the EEA MIF and the proportion of the overcharge passed on to the proposed classes.

While it was common ground that the MSC overcharge was fully passed onto merchants, it was more difficult to determine the level of pass-on to consumers. The difficulties arise from the different time periods and product and market sectors subject to the charge in the UK economy. The experts assumed a single weighted average for the different levels of MSC Pass-on. In considering the likely level of the 'pass-on' rate, the experts placed considerable importance on the position taken by Mastercard and their experts in previous litigation. In a claim brought by Sainsbury's, a UK supermarket, in relation to the MSC, Mastercard's expert evidence was to the effect that the level of pass-on by Sainsbury's to consumers was closer to $100 \%$ than to $50 \% .^{18}$

\section{The common issues of fact or law}

The experts' assessment was based on a 'top-down' method on a 'global or class-wide basis in terms of the amount of the overcharge passed on to consumers generally without the need to calculate how each member of the represented class was affected. ${ }^{19}$ To be eligible for inclusion in collective proceedings the claim must raise common issues of fact or law (s47B(6) CA). The CAT was concerned that the proposed methodology for calculating the level of pass-on of the MIFs from merchants to consumers as a whole, identifying a global loss suffered by consumers, may not constitute a common issue absent being able

\footnotetext{
18 Merricks [2019] EWCA Civ 674 [9]; Sainsbury's v Mastercard [2016] CAT 11.

19 Merricks [2019] EWCA Civ 674 [19].
} 
to show that each member of the class was in some way adversely affected in their own purchases during the infringement period. ${ }^{20}$

The Court of Appeal pointed out however that the CAT had accepted that not all of the issues need to be common issues in order for the collective claim to be certified. ${ }^{21}$ There was also no requirement under Section $47 \mathrm{C}(2) \mathrm{CA}$ to approach the assessment of an aggregate award through the medium of a calculation of individual loss. ${ }^{22}$ The Court stated that '[p]ass-on to consumers generally satisfies the test of commonality of issue necessary for certification. ${ }^{23}$

\section{The sufficiency of data for the grant of the CPO}

While the CAT had accepted that a method of calculation of global loss through a weighted average pass-on was methodologically sound, they acknowledged that this required access to a wide range of data. Given the preliminary nature of the information available, the crucial question for the CAT was what amounts to 'sufficient data' for the methodology to be applied for the grant of the CPO? While the CAT did not expect a full analysis to be carried out 'a proper effort would have had to be made to determine whether it is practicable by ascertaining what data is reasonable available'. ${ }^{24}$

The CAT relied on the Canadian Supreme Court decision in Pro-Sys Consultants Ltd v Microsoft Corp. [2013] SCC 57 (hereinafter: Microsoft), which considered overcharges paid to Microsoft for the purchase of software by indirect purchasers:

Accordingly, applying the Microsoft test (para 58 above), we are unpersuaded on the material before us that there is sufficient data available for this methodology to be applied on a sufficiently sound basis. It follows that we are not satisfied, and

20 Merricks [2019] EWCA Civ 674 [45].

${ }^{21}$ Merricks [2019] EWCA Civ 674 [46].

22 The Tribunal may make an award of damages in collective proceedings without undertaking an assessment of the amount of damages recoverable in respect of the claim of each represented person: Section 47C9(2) CA.

23 Merricks [2019] EWCA Civ 674 [47]. The Court of Appeal stated that the ability to treat the loss caused to consumers as a class as a common issue 'was dependent on the availability of an economic model and methodology that was capable of making that global (and therefore common) assessment', citing the Canadian Supreme Court decision in Pro-Sys Consultants Ltdv Microsoft Corp. [2013] SCC 57 at [115]: Merricks [2019] EWCA Civ 674 [43]; Section 4(1)(c) of the Canadian Competition Act 1985 requires the claims of the class members to raise common issues which are defined as meaning 'common but not necessarily identical issues of fact'.

${ }^{24}$ Merricks [2017] CAT 16 [77]. 
indeed very much doubt, that the claims are suitable for an aggregate award of damages: see rule 79(2)(f). ${ }^{25}$

The CAT went on to cite Rothstein J from the Microsoft judgment:

... the expert methodology must be sufficiently credible or plausible to establish some basis in fact for the commonality requirement. This means that the methodology must offer a realistic prospect of establishing loss on a class-wide basis so that, if the overcharge is eventually established at the trial of the common issues, there is a means by which to demonstrate that it is common to the class (i.e. that passing on has occurred). The methodology cannot be purely theoretical or hypothetical, but must be grounded in the facts of the particular case in question. There must be some evidence of the availability of the data to which the methodology is to be applied. ${ }^{26}$

While the CAT and Court of Appeal were not bound to follow Canadian authorities, the Court of Appeal noted that they were useful, due to the similarities between the two class action provisions. ${ }^{27}$ The Court found however that the CAT had committed an error of law by applying the wrong test in setting the standard of evidence as too high for the CPO stage. The Court of Appeal stated:

It seems to us that at the certification stage the proposed representative must be able to demonstrate that the claim has a real prospect of success. To do so in this case he had to satisfy the CAT that the expert methodology was capable of assessing the level of pass-on to the represented class and that there was, or was likely to be, data available to operate that methodology. But it was not necessary at that stage for the proposed representative to be able to produce all of that evidence, still less to enter into a detailed debate about its probative value. ${ }^{28}$

\section{The Court of Appeal went on to state:}

The availability of data sufficient to allow the methodology to be operated on what the CAT described as a sufficiently sound basis ought at the certification stage to be looked at in terms of what information can be made available for use at the trial. ${ }^{29}$

25 Merricks [2017] CAT 16 [78].

26 Pro-Sys Consultants Ltd v Microsoft Corp. [2013] SCC 57 [118], cited by Merricks [2017] CAT 16 [58].

27 The Court of Appeal stated: 'Our view is that the CAT was right to treat the Canadian jurisprudence on certification as informing the correct approach. Most of the provinces in Canada have enacted class proceedings legislation (not limited to competition cases)': Merricks [2019] EWCA Civ 674 [40]. For a thorough review of the Canadian and United States class action jurisprudence relating to this case: see Mulheron and Edlin, 2018.

28 Merricks [2019] EWCA Civ 674 [44].

29 Merricks [2019] EWCA Civ 674 [50]. 
It was sufficient at certification stage that the proposed methodology was credible, it was not appropriate at the certification stage to require the proposed representative and his experts to specify in detail what data would be available for each of the relevant retail sectors in respect of the infringement period.' 30

The CAT had rather carried out a form of mini-trial and required the representative to establish more than a reasonably arguable case, ${ }^{31}$ which therefore 'exposed the claim to a more vigorous process of examination than would have taken place at a strike-out application. ${ }^{32}$ This also ignored that certification is a continuing process under which a CPO may be varied or revoked at any time $(\mathrm{s} .47 \mathrm{~B}(9)) .{ }^{33}$ At the certification stage, the proposed representative should not 'be required to demonstrate more than that he has a real prospect of success. This is not the test which the CAT applied.' ${ }^{34}$

\section{The method of distribution of the aggregate award}

The second issue for the refusal by the CAT of the CPO concerned the proposed method of distribution of the aggregate award which the CAT stated would bear no relation to the actual loss suffered by individual members of the class and therefore conflict with the principle of compensation of damages.

This issue was related to the methodology of seeking to calculate the loss on a top-down, aggregate basis and seeking to award the class on a per capita basis for each separate year of the infringement period and 'not on the basis of a common issue concerning loss suffered by each member (or most members) of the class'. ${ }^{35}$

The Court of Appeal however found that the CAT had committed an error of law by wrongly directing itself to refuse certification by reference to the proposed distribution method..$^{36}$ Section $47 \mathrm{~B}$ and the Rules do not determine any particular form of distribution and the provisions are open-ended. ${ }^{37}$ The CAT is merely required to determine whether the claims are suitable for

30 Merricks [2019] EWCA Civ 674 [51].

31 Merricks [2019] EWCA Civ 674 [52].

32 Merricks [2019] EWCA Civ 674 [53]. Williams and Bates query whether this lower standard is in keeping with the 'strong safeguard' envisaged by the UK Government in devising the collective proceedings scheme: See Williams and Bates, 2019, p. 333.

33 Merricks [2019] EWCA Civ 674 [53].

34 Merricks [2019] EWCA Civ 674 [54].

35 Merricks [2017] CAT 16 [87].

${ }^{36}$ Merricks [2019] EWCA Civ 674 [62].

37 Merricks [2019] EWCA Civ 674 [60]. 
an aggregate award of damages and this does not include the assessment of individual loss (Rule 79(2)(f)). The actual mode of distribution need also not be considered at the certification stage, as it is a matter for determination at trial. ${ }^{38}$

The purpose of a collective action is to encourage suits not available individually, and so to require the calculation of individual loss for the authorisation of a distribution at the CPO stage would largely negate these large-scale opt-out proceedings. ${ }^{39}$ The Court of Appeal stated: '[t]he vindication of the rights of individual claimants is achieved by the aggregate award itself.' 40

The Court of Appeal set aside the order and remitted it to the CAT for re-hearing.

\section{Conclusion}

The Court of Appeal decision in Merrricks provides an important indicator of the likely success of future collective proceedings under the new UK regime. The standard set by the Court of Appeal that the claim at the CPO stage has a 'real prospect of success' whereby the expert methodology is capable of assessing the pass-on (credible) and there is (or likely to be) data available to operate that methodology, is a fairly low threshold that will encourage future cases.

The Court has also found that to make the aggregate award of damages subject to the assessment of the loss suffered and recoverable by each individual would annul the purpose of the power to make collective awards. Williams and Bates argue that this approach "effectively dispenses with the requirement for each, or even any, of the individual claims comprised within a collective action to be made out. Instead, the requirement for loss to be shown (which is normally a necessary ingredient of a claim for breach of statutory duty) is replaced with a requirement that some (not necessarily identified or identifiable) members of the class suffered loss (Williams and Bates, 2019, p. 335). But as Mulheron and Edlin point out, the compensatory principle is not statutorily mandated under the new collective scheme (Mulheron and Edlin, 2018, p. 242) and the representative 'is not expected to produce a methodology that each and every class member suffered some loss. ${ }^{31}$ While s47B(1) CA provides that collective

\footnotetext{
38 Merricks [2019] EWCA Civ 674 [62].

39 Merricks [2019] EWCA Civ 674 [57].

${ }^{40}$ Merricks [2019] EWCA Civ 674 [61].

41 Ibidem, 235.
} 
proceedings may be brought 'combining two or more claims', it is clear that they are perceived to differ from a mere summation of individual claims.

The reliance by the Court of Appeal and the CAT on Canadian jurisprudence will provide an important source of interpretation for future certification decisions. The Canadian Supreme Court noted in the Microsoft case that the methodology 'cannot be purely theoretical or hypothetical but must be grounded in the facts. ${ }^{42}$ The Canadian court stressed the importance of certification as a 'meaningful screening device' and the 'standard for assessing evidence at certification does not give rise to "a determination of the merits of the proceeding" ( $C P A$, s. 5(7)); nor does it involve such a superficial level of analysis into the sufficiency of the evidence that it would amount to nothing more than symbolic scrutiny. ${ }^{43}$

In assessing these questions and ensuring that the $\mathrm{CPO}$ is a 'meaningful screening device' it may be difficult for future Tribunals to effectively draw the line between conducting a 'mini trial' and establishing a 'real prospect of success' that is grounded in fact. At the same time, given the complexities and costs faced by representatives to access and analyze data at the CPO stage, if the CAT applies the correct test in future cases it may be difficult to set aside cases on judicial review because these questions, in the absence of error of law, are for the CAT to decide. The judgment provides a strong statement of the legal test that the CAT should observe at the certification stage and reasserts the importance of the collective proceedings as a valuable means of redress for competition law damages. The decision has now been appealed to the UK Supreme Court where these issues may be further clarified. If upheld by the Supreme Court, it will be interesting to observe how the CAT deals with both this remitted and future decisions.

\section{Literature}

Mulheron R., Edlin D. (2018). The mere mirage of a class action? A challenge to Merricks v Mastercard Inc', 37(2) Civil Justice Quarterly 216-256.

Williams J., Bates A. (2019). A priceless victory for consumers: the Court of Appeal revitalises competition law's collective actions: Merricks v Mastercard [2019] EWCA Civ 674, 38(3) Civil Justice Quarterly 327.

42 Pro-Sys Consultants Ltd v Microsoft Corp. [2013] SCC 57 [118].

${ }^{43}$ Microsoft, ibid [103] referring to Hollick v Toronto (City) 2001 SC 68, cited in Merricks [2019] EWCA Civ 674 [41]. 